\title{
What drives large-scale glacier detachments? Insights from Flat Creek glacier, St. Elias Mountains, Alaska
}

\author{
Mylène Jacquemart ${ }^{1}$, Michael Loso ${ }^{2}$, Matthias Leopold ${ }^{3}$, Ethan Welty ${ }^{4}$, Etienne Berthier ${ }^{5}$, Jasmine S.S. Hansen ${ }^{1}$, \\ John Sykes ${ }^{6}$ and Kristy Tiampo ${ }^{1}$ \\ 1Department of Geological Sciences \& Cooperative Institute for Research in Environmental Sciences (CIRES), \\ University of Colorado, Boulder, Colorado 80309, USA \\ 2Wrangell-St. Elias National Park and Preserve, Copper Center, Alaska 99573, USA \\ ${ }^{3}$ School of Agriculture and Environment, University of Western Australia, Perth, WA 6009, Australia \\ ${ }^{4}$ Institute of Arctic and Alpine Research (INSTAAR), University of Colorado, Boulder, Colorado 80309, USA \\ ${ }^{5}$ Laboratoire d'Études en Géophysique et Océanographie Spatiales (LEGOS), Université de Toulouse, 31400 Toulouse, France \\ ${ }^{6}$ Department of Geography, Simon Fraser University, Burnaby, BC V5A 1S6, Canada
}

\begin{abstract}
Two large-scale glacier detachments occurred at the peaks of the 2013 and 2015 CE melt seasons, releasing a cumulative $24.4-31.3 \times 10^{6} \mathrm{~m}^{3}$ of ice and lithic material from Flat Creek glacier, St. Elias Mountains, Alaska. Both events produced highly mobile and destructive flows with runout distances of more than $11 \mathrm{~km}$. Our results suggest that four main factors led to the initial detachment in 2013: abnormally high meltwater input, an easily erodible glacier bed, inefficient subglacial drainage due to a cold-ice tongue, and increased driving stresses stemming from an internal redistribution of ice after 2011. Under a drastically altered stress regime, the stability of the glacier remained sensitive to water inputs thereafter, culminating in a second detachment in 2015. The similarities with two large detachments in the Aru mountains of Tibet suggest that these detachments were caused by a common mechanism, driven by unusually high meltwater inputs. As meltwater production increases with rising temperatures, the possible increase in frequency of glacier detachments has direct implications for risk management in glaciated regions.
\end{abstract}

\section{INTRODUCTION}

Large-scale glacier detachments occur when large portions of valley glaciers' tongues decouple from the glacier bed, resulting in catastrophic mass flows (Evans and Delaney, 2015). Recent observations from around the world, including the $2002 \mathrm{CE}$ detachment of Kolka glacier in Russia $\left(100-130 \times 10^{6} \mathrm{~m}^{3}\right.$; Haeberli et al., 2004; Evans et al., 2009), the twin 2016 detachments of the Aru glaciers in Tibet $\left(68 \times 10^{6} \mathrm{~m}^{3}\right.$ and $83 \times 10^{6} \mathrm{~m}^{3}$, respectively; Kääb et al., 2018), the 2007 detachment of Leñas glacier in the Argentinian Andes ( $4 \times 10^{6} \mathrm{~m}^{3}$; Falaschi et al., 2018), and repeated ice detachments from an unnamed glacier in central China (unknown volume; Paul, 2019), raise the question whether anthropogenic climate change is not only accelerating glacier retreat, but also introduc- ing a previously unobserved yet catastrophic mechanism of glacier destruction.

We extend the list above by documenting two large-scale detachments at Flat Creek glacier, Alaska, which occurred in 2013 and 2015. Understanding the cause of these hazardous events is critical to predicting where else they are likely to occur. Although Gilbert et al. (2018) proposed that the Aru and Kolka detachments were ultimately caused by a failure of the subglacial till, the climatic and glacial conditions leading up to these detachments differed significantly (Gilbert et al., 2018; Evans et al., 2009). In this study, we used data from two field campaigns and a remote-sensing analysis to characterize the geologic, glacial, thermal, and meteorological conditions that led to the Flat Creek detachments. In an attempt to identify common drivers of glacier detachments, we described and quantified the Flat Creek detachments and compared them to those of Aru and Kolka.

\section{STUDY AREA}

Prior to the 2013 detachment, informally named Flat Creek glacier covered $2.6 \mathrm{~km}^{2}$ $(6.5 \%)$ of the Flat Creek watershed (Fig. 1). It occupied a central trough at 2030-2650 m above sea level (asl) on the NNE-facing headwall. Meltwater from the glacier drains into the White River at $1050 \mathrm{~m}$ asl. The glacier lies in a subarctic climate in the rain shadow of the St. Elias Mountains. Over the last decade, the Chisana weather station $(50 \mathrm{~km}$ northwest of Flat Creek, at $1012 \mathrm{~m}$ asl) recorded a mean annual air temperature of $-4.5^{\circ} \mathrm{C}$ and a mean annual precipitation of $335 \mathrm{~mm}$. Regional and global maps (Jorgenson et al., 2008; Gruber, 2012), electrical resistivity tomography, and ground temperature measurements (see methods in the Supplemental Material $^{1}$ ) indicate that permafrost is continuous in the upper part of the valley (above $1800 \mathrm{~m}$ asl) and discontinuous-to-sparse on the alluvial fan (below $1600 \mathrm{~m}$ asl). Many glaciers in the area have a history of surging (Post, 1969), and one glacier adjacent to Flat Creek surged between 2012 and 2015. Crosscutting upper Flat Creek, the influence of the Totschunda fault (Schwartz et al., 2012) is apparent in heavily fractured, thin-bedded silt and sandstones of the Permian Hasen Creek Formation that underlie the valley's glaciers. Just downstream, the lithology changes to volcaniclastic sediments of the Nikolai Greenstone Formation (MacKevett, 1978).

${ }^{1}$ Supplemental Material. Descriptions of datasets, analysis methods, and processing code. Please visit https://doi.org/10.1130/GEOL.26213S.12107055 to access the supplemental material, and contact editing@geosociety.org with any questions.

CITATION: Jacquemart, M., et al., 2020, What drives large-scale glacier detachments? Insights from Flat Creek glacier, St. Elias Mountains, Alaska: Geology, v. 48 , p. , https://doi.org/10.1130/G47211.1 


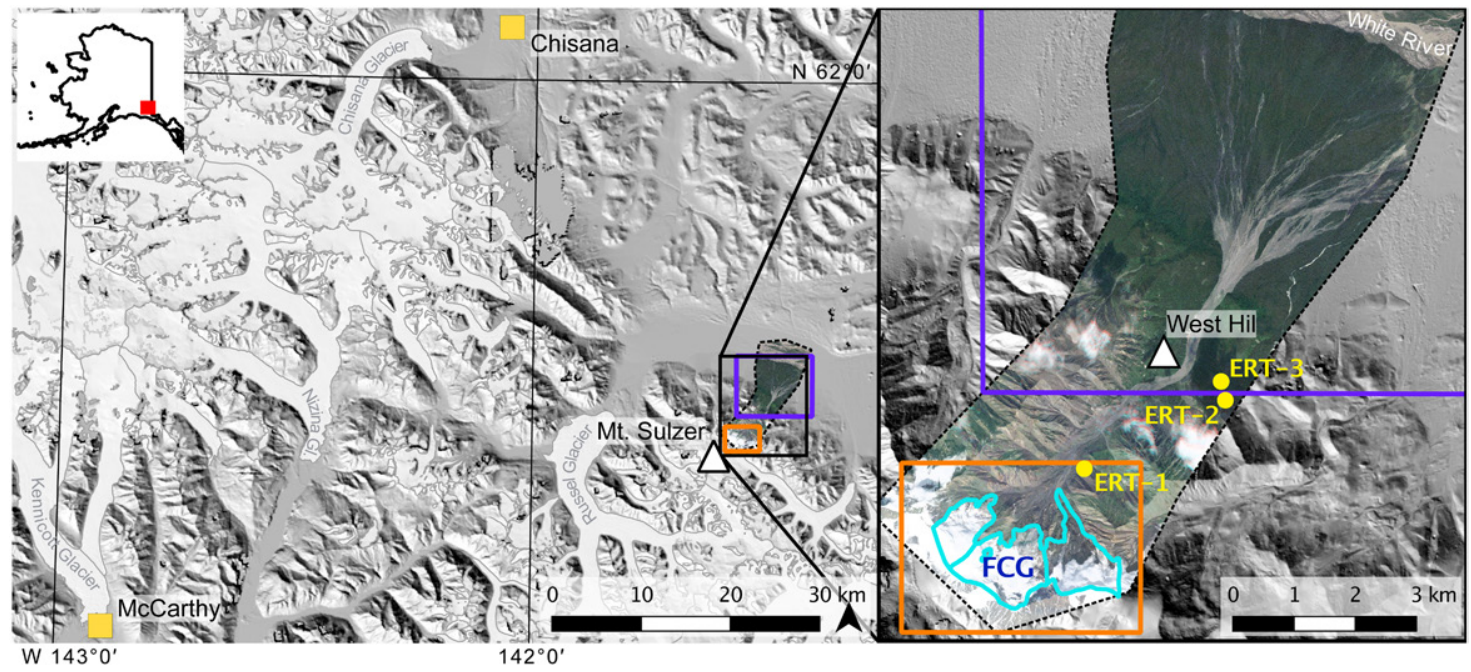

Figure 1. Study area in Alaska. Glacier and alluvial-fan changes (orange and purple box, respectivey) are shown in detail in Figure 2. Yellow dots indicate locations of electrical resistivity tomography (ERT) surveys; ground temperatures were measured at ERT-1. Cyan lines are from Randolph Glacier Inventory $\mathbf{6 . 0}$ (RGI Consortium, 2017). FCG-Flat Creek glacier; GI.-glacier. Note that the background image shows the watershed prior to the detachments (@) Planet Team, 2018; image republished with permission).

\section{FLAT CREEK GLACIER DETACHMENTS}

On 5 August 2013, the lowermost $500 \mathrm{~m}$ section of Flat Creek glacier (below $2270 \mathrm{~m}$ asl) detached and traveled $11 \mathrm{~km}$ downstream (Fig. 2). The remaining ice responded rapidly, advancing $30-45 \mathrm{~m}$ in the days following the detachment (measured with orthophotos from 11 August 2013 and 5 September 2013) and thinning by up to $28.1 \pm 0.7 \mathrm{~m}$ (Fig. 3). We estimated elevation changes by differencing two digital elevation models (DEMs) from before and after the detachment (26 August 2012 and 12 October 2014). The total detachment volume was $6.8 \pm 0.2 \times 10^{6} \mathrm{~m}^{3}$ to $11.2 \pm 0.7 \times 10^{6} \mathrm{~m}^{3}$ (Fig. 3 ; see methods in the Supplemental Material). The lower bound only considers the elevation difference in the detachment zone. The upper bound further includes the thinning of the upper glacier as an estimate of the volume that advanced into the detachment zone in response to the collapse.

Throughout summer 2013 to spring 2015, the remaining glacier advanced and crumbled at the front, covering the original detachment zone with loose ice. Sometime between 18 July and 25 July 2015, this loose ice detached and traveled $10 \mathrm{~km}$ down the valley (see the Supplemental Material). On 30 July 2015, another $17.6 \pm 0.2 \times 10^{6} \mathrm{~m}^{3}$ to $20.1 \pm 0.3 \times 10^{6} \mathrm{~m}^{3}$ of ice and lithic material detached. This failure reached the drainage divide at $2650 \mathrm{~m}$ asl (Figs. 2 and 3). The resulting mass flow spread debris over $8 \mathrm{~km}^{2}$ of the alluvial fan, burying $3 \mathrm{~km}^{2}$ of mature forest (at least four centuries old; see the Supplemental Material). The angle of the exposed glacier bed, presumably the failure plane, was $21^{\circ}$ above horizontal.

In both 2013 and 2015, the detached masses transformed into highly mobile mass flows that reached the White River (12 km downstream) in minutes and ran an average of $76 \mathrm{~m}$ up the back of West Hill, a prominent bedrock knob adjacent to Flat Creek (Fig. 1). Using runup heights (Iverson et al., 2016; Prochaska et al., 2008)
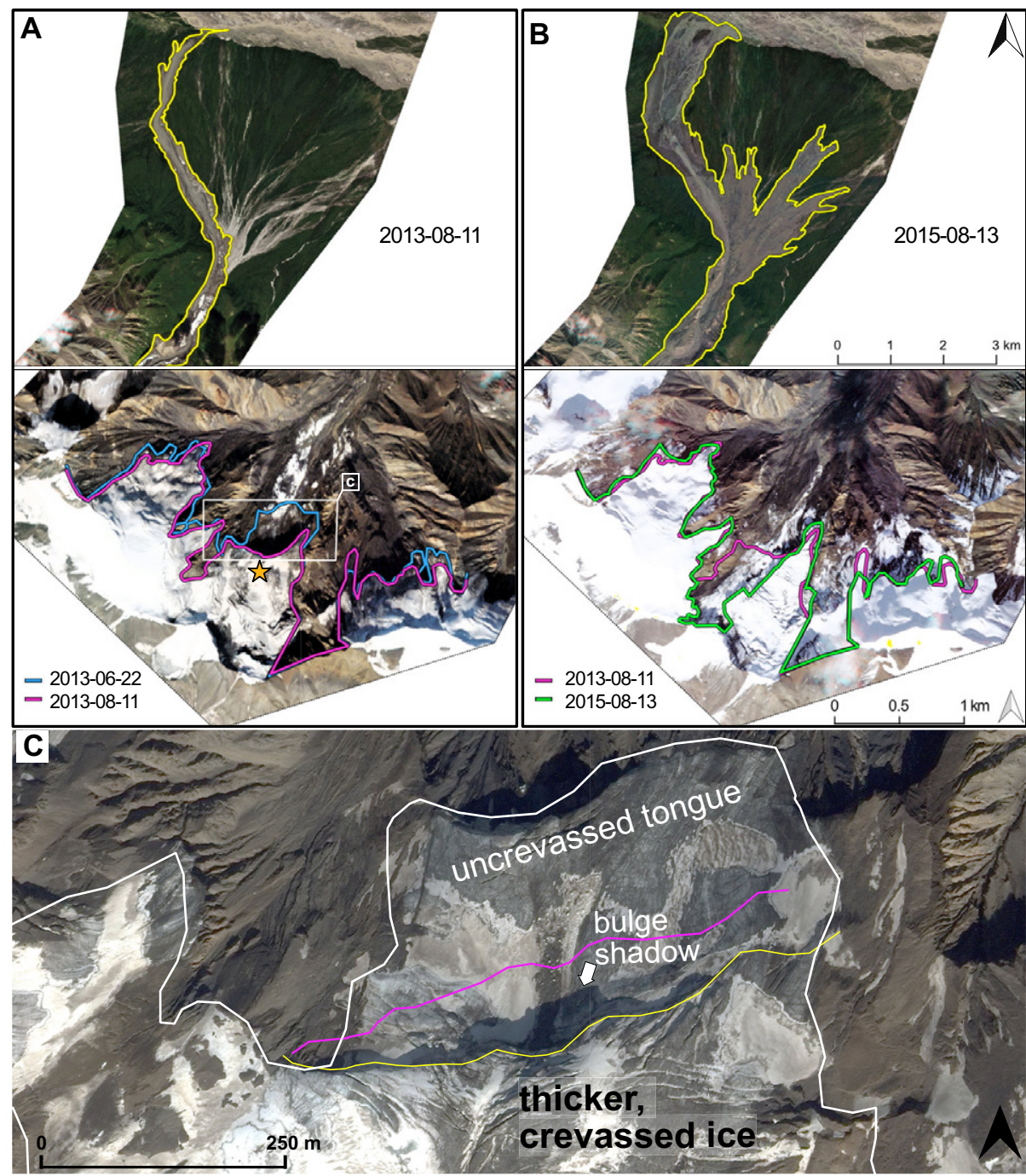

Figure 2. Changes of Flat Creek glacier (Alaska) and alluvial fan (orange and purple box in Fig. 1). (A) Image from 11 August 2013. Orange star indicates accumulation point of water based on flow accumulation analysis. (B) Image from 13 August 2015. All images ( ) Planet; images republished with permission. (C) Crevasse-free tongue of Flat Creek glacier and thicker, crevassed ice upstream. Ikonos image from 13 July 2009. The shadow used to estimate bulge height is indicated with the white arrow. Yellow and magenta lines are the edge of the bulge in 2009 and 2013, respectively. (- Maxar 2020; image republished with permission. Dates are yyyy-mm-dd format. 

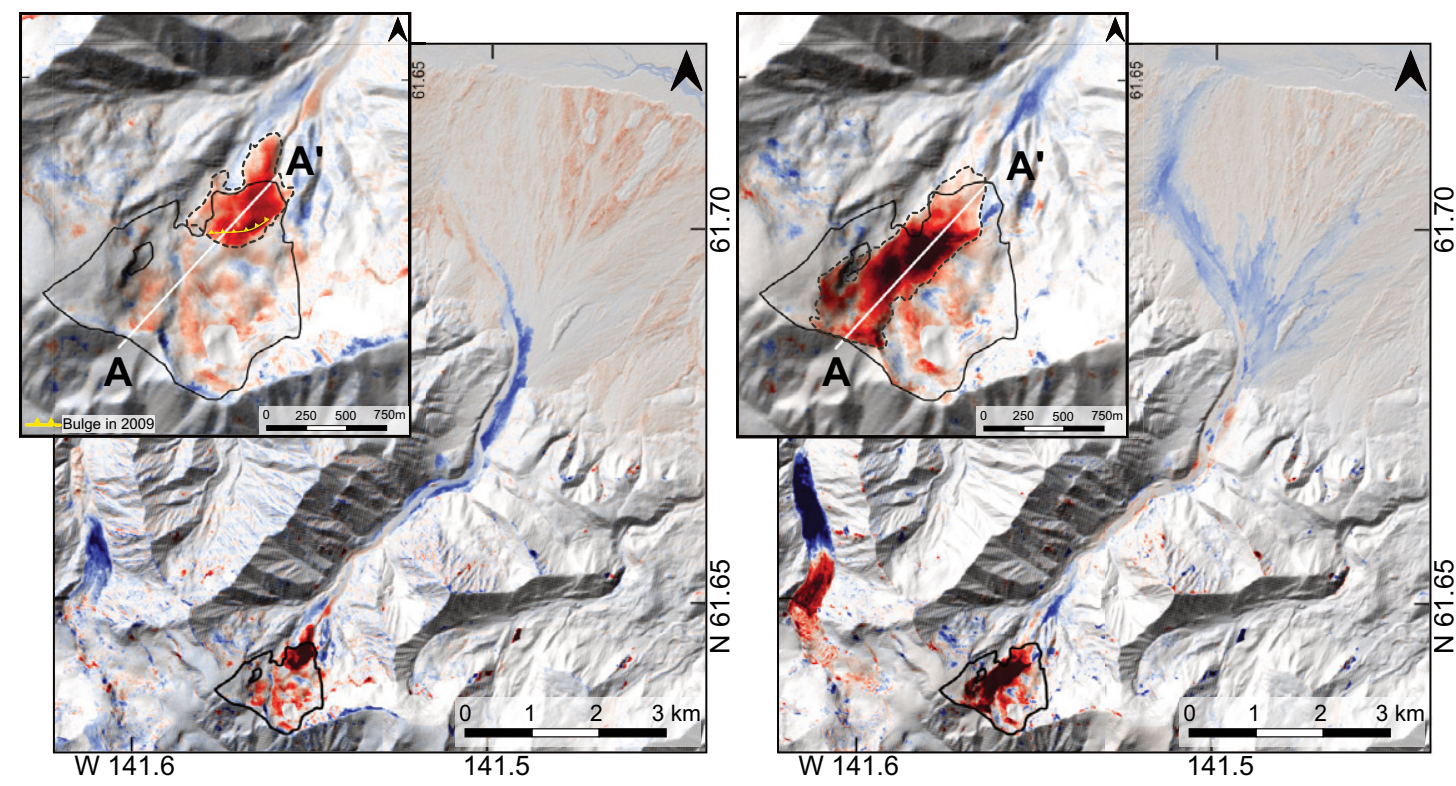

A Profile view of Flat Creek Glacier detachments
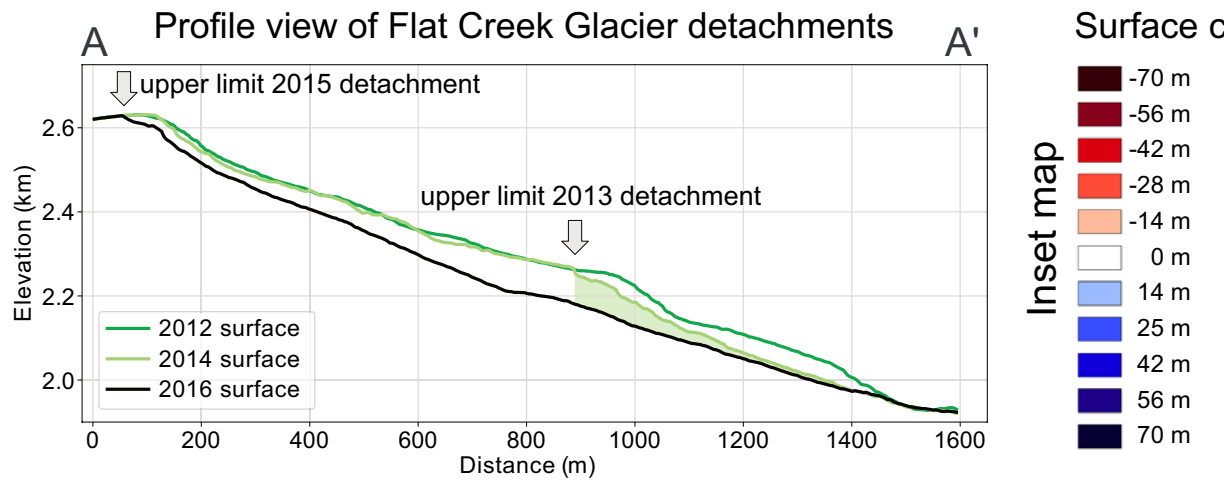

and the duration of the detachment-induced quakes recorded at the Barnard glacier seismic station (60 km southwest of Flat Creek), we derived peak velocities up to $50 \mathrm{~m} / \mathrm{s}$ and mean velocities around $30 \mathrm{~m} / \mathrm{s}$ for both events (see the Supplemental Material). Surveying the detachment deposits in 2018 and 2019, we found finegrained lithic material $(30 \%-40 \%$ clay; see the Supplemental Material) mixed with interstitial ice and rounded ice blocks. The lithic material was almost exclusively Hasen Creek mudstone from under the glacier.

\section{DETACHMENT DRIVERS}

Photographs of the detachment zone acquired with an unmanned aerial vehicle in 2018 show that the thin-bedded mud and sandstones eroded into thick layers of fine-grained, unconsolidated sediment. Despite the proximity of the Totschunda fault, we found no seismic triggers for the detachments in the U.S. Geological Survey (USGS) earthquake record.

One of Flat Creek glacier's remarkable features before the first detachment was thick, bulging ice behind a thin, crevasse-free tongue (Fig. 2). From the length of the shadows cast by the bulge in a 13 July 2009 orthophoto, we constrained the maximum height of the bulge to $70.2 \pm 9.4 \mathrm{~m}$ (see methods in the Supplemental Material). We ruled out the possibility that the bulge was caused by a bedrock step because the postdetachment DEM showed no such feature, and it is unlikely that such a feature would have endured centuries of glacial erosion yet disintegrated during the detachment (Fig. 3). We found no change in the horizontal position of the bulge between 2009 and 2011. However, between 2011 and 22 June 2013 (coincident with the surge of the glacier in the adjacent drainage), satellite images show that the bulge advanced by as much as $100 \mathrm{~m}$ (Fig. 2; see the Supplemental Material), suggesting that a mass redistribution was under way. In contrast, the glacier terminus did not advance during this time, supporting our inference of a cold-ice tongue. The bulge and cold-ice tongue very closely resemble the geometry observed in 1980 on Trapridge glacier, $80 \mathrm{~km}$ to the southeast (Clarke and Blake, 1991). Englacial temperature measurements on Trapridge glacier showed that a thin, cold-ice tongue served as a mechanical dam to temperate ice up glacier, forming the bulge. Given the morphological similarities to Trapridge glacier, a mean annual air temperature of $-12.1^{\circ} \mathrm{C}$ at
Figure 3. Top left: Surface elevation change between 26 August 2012 and 12 October 2014. Top right: Surface elevation change between 12 October 2014 and 13 March 2016. The 2012 elevation data is from the Alaska interferometric synthetic aperture radar digital elevation model (DEM); the 2014 and 2016 datasets are from ArcticDEM (Porter et al., 2018). Inset maps resolve more detail over the detachments (dashed outlines); black line is the original glacier outline. Note ongoing surge of the glacier west of Flat Creek. Bottom: Longitudinal profiles from 2012, 2014, and 2016. Below the 2013 detachment line, loose ice (area shaded green) masked the full surface change. the predetachment terminus, and continuous permafrost in the headwall, we conclude that Flat Creek glacier was polythermal, with a thin cold-ice tongue slowing the advance of thicker, temperate ice up-glacier.

Based on Flat Creek glacier's thermal regime, we infer that subglacial drainage was restricted by the cold-ice tongue. Glacier marginal streams and deeply incised supraglacial streams on many of the region's small glaciers suggest that this mechanism is common in this area (Irvine-Fynn et al., 2011; Ryser et al., 2013). Observations from Trapridge glacier suggest that water likely drains through the subglacial substrate to icemarginal streams, and we suggest the same was true at Flat Creek glacier. The limited efficiency of this drainage mechanism causes water to accumulate if the input rate exceeds the output rate (Clarke et al., 1984; Clarke and Blake, 1991). To identify where below Flat Creek glacier water would have accumulated, we applied a Rho8 flow-routing analysis to the 26 August 2012 DEM (Fairfield and Leymarie, 1991; see also methods in the Supplemental Material). Glacier surface topography was taken to be an acceptable catchment-level proxy for water drainage below the glacier (Ignéczi et al., 2018). 
We found that the area immediately upstream of the bulge received water from a larger catchment than any other point on the glacier. The next highest flow concentrations were under the detachment zone. Given this large drainage area and the crevassed surface of the glacier upstream of the bulge, meltwater likely reached the bed and increased the subglacial water pressure.

To evaluate the availability of liquid water prior to the detachments, we used a 36 yr record of dynamically downscaled ERA-Interim (ECMWF, Reading, UK) temperature and precipitation data available for Alaska at $20 \mathrm{~km}$ resolution (Bieniek et al., 2016; see methods in the Supplemental Material), bias-corrected with $10 \mathrm{yr}$ of weather station data from Chisana. Since both failures happened during peak melt season, we calculated the cumulative summer water availability for each year by summing rainfall and melt from April through July. Melt was modeled at an hourly resolution using a degree-day approach with melt factors of $2.7 \mathrm{~mm} \mathrm{~d}^{-1}{ }^{\circ} \mathrm{C}^{-1}$ for snow and $4.87 \mathrm{~mm} \mathrm{~d}^{-1}{ }^{\circ} \mathrm{C}^{-1}$ for ice (see methods in the Supplemental Material; Hock, 2003). At Flat Creek, according to our model, the cumulative summer water availability preceding the 2013 detachment exceeded the $36 \mathrm{yr}$ mean cumulative summer water availability by $100 \%-615 \%$, or $3.59-4.77$ standard deviations $(\sigma)$, depending on elevation (Fig. 4). Water availability was lower than average $(-0.49 \sigma$ to $0.03 \sigma$ ) in 2014 , but again exceeded the mean by $0.08 \sigma-0.91 \sigma$ in 2015 .

\section{DISCUSSION}

The apparent emergence of large-scale glacier detachments (Kääb et al., 2018; Falaschi et al., 2018; Paul, 2019; Jacquemart and Loso, 2019) raises the question of whether these events share common drivers, and whether these will be exacerbated by current warming.

The 2013 detachment at Flat Creek glacier coincided with unprecedented water availability driven by record warm temperatures. Our modeled water availability is supported by Alaska-wide measurements showing 2013 to be the year with the most negative mass balance since 2003 (Wouters et al., 2019). Due to the inefficient drainage mechanism identified at
Flat Creek glacier, the high melt rates allowed water to accumulate under the glacier, increasing the water pressure in the subglacial till and weak bedrock. The ultimate shear strength of subglacial till has been shown to increase linearly with effective normal stress (Iverson et al., 1998). By reducing the effective pressure, increasing basal water pressure is therefore likely to have weakened the subglacial till. Indeed, the high clay content of the deposits indicates that the failure initiated within the glacier's basal substrate. Meanwhile, the advancing bulge upstream of the cold-ice tongue contributed to increased driving stresses. When meltwater input peaked in July 2013, rising subglacial water pressures and increased driving stresses allowed the glacier tongue to detach $\sim 100 \mathrm{~m}$ upstream of the 2009-2011 location of the bulge.

In 2015, the geometry of the glacier was dramatically altered, and we assume that all remaining ice was temperate. However, the inverse correlation between water availability and glacier stability, and the role of the weak basal substrate, continued. No detachment occurred in 2014, when water availability was below average, but activity resumed with increasing water availability in 2015 . The precursory detachment of the loose ice accumulated in the detachment zone shows how easily the underlying lithic material failed with increased water availability. Under the remaining glacier, the stability of the till may have been compromised by two factors following the 2013 detachment: (1) reduction of the effective normal stress due to thinning of the glacier (though this also reduces driving stresses), and (2) alignment of clay particles by the glacier advance, an effect that has also been shown to reduce the shear strength of glacial tills (Iverson et al., 1998). Combined, these factors likely contributed to the 2015 detachment, and they also highlight that a polythermal regime is not a mandatory prerequisite for a large-scale detachment.

Both the 2013 and 2015 mass flows impacted a large swath of $400 \mathrm{yr}$ old forest, indicating that no event of comparable size has occurred here in the past four centuries. This suggests that largescale glacier detachments may indeed be a new hazard of our warming world.

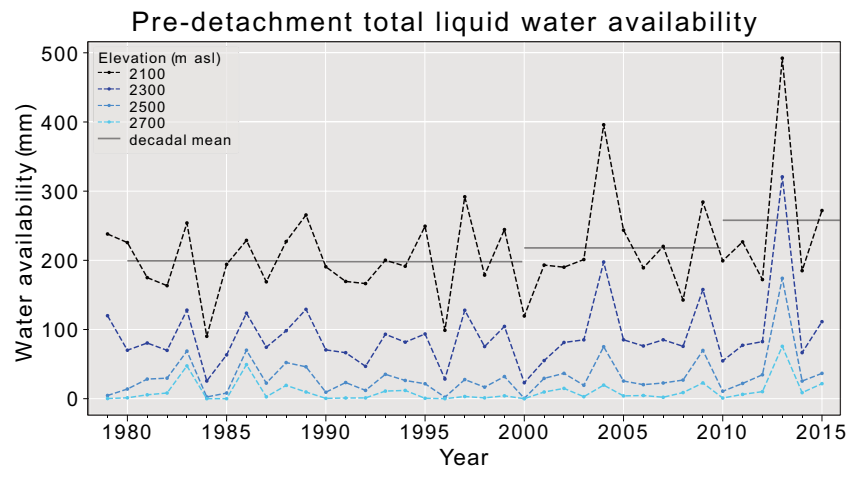

A comparison with the Kolka and Aru detachments revealed that conditions at Flat Creek strongly resembled those at Aru, but not those at Kolka. Kolka glacier is temperate, and the stress regime was likely altered by an accumulation of debris from a series of ice and rock falls (Haeberli et al., 2004; Evans et al., 2009). In contrast, the cold-ice margins of the Aru glaciers allowed water to accumulate in the subglacial till over the 5-6 yr preceding the detachments. Simultaneously, increasing flow velocities were observed on bulging, temperate ice encroaching upon the tongues of both glaciers, increasing driving stresses (Gilbert et al., 2018). Under this altered stress regime, the accumulation of water decreased the effective normal stress on the till, inducing failure in 2016, the year with the highest recorded degree-day sum (Kääb et al., 2018).

In conclusion, insights from this study suggest that remarkably similar glacial and climatic conditions led to the Flat Creek and Aru detachments. At Flat Creek glacier, these conditions led to two detachments, which both produced highly destructive mass flows with wide-reaching impacts, luckily without human casualties or damage to infrastructure. Our work highlights the potential sensitivity of soft-bedded polythermal glaciers to sudden detachments under warming conditions, and the need to refine the criteria that distinguish collapse-prone glaciers from others in this broad category. Identifying those glaciers that are mostly likely to detach is critical to risk management in mountain environments.

\section{ACKNOWLEDGMENTS}

We acknowledge a NASA Earth and Space Science Fellowship for M. Jacquemart, and funding from the U.S.National Park Service Inventory and Monitoring Program. E. Berthier acknowledges Centre National d'Etudes Spatiales (CNES) funding (France). Field work was partially funded under NASA Interdisciplinary Research in Earth Science (IDS) award 80NSSC17K0017, as was K. Tiampo. We thank J. Trop, T. Vaden, P. Claus, and L. Wassink for early field observations. Valuable input was received from A. Kääb, M. Dokukin, K. Allstadt, D. Farinotti, A. Vieli, W. Haeberli, and G. Wolken. We thank R. Hooke and A. Gilbert, as well as one anonymous reviewer, for their valuable comments.

\section{REFERENCES CITED}

Bieniek, P.A., Bhatt, U.S., Walsh, J.E., Rupp, T.S., Zhang, J., Krieger, J.R., and Lader, R., 2016, Full access dynamical downscaling of ERA-Interim temperature and precipitation for Alaska: Journal of Applied Meteorology and Climatology, v. 55, p. 635-654, https://doi.org/10.1175/JAMC-D-15-0153.1.

Clarke, G.K.C., and Blake, E.W., 1991, Geometric and thermal evolution of a surge-type glacier in its quiescent state: Trapridge glacier, Yukon Territory, Canada, 1969-89: Journal of Glaciology, v. 37, p. 158-169, https://doi.org/10.1017/ S002214300004291X.

Clarke, G.K.C., Collins, S.G., and Thompson, D.E., 1984, Flow, thermal structure, and subglacial conditions of a surge-type glacier: Canadian Journal of Earth Sciences, v. 21, p. 232-240, https://doi .org/10.1139/e84-024. 
Evans, S.G., and Delaney, K.B., 2014, Catastrophic mass flows in the mountain glacial environment, in Haeberli, W., and Whiteman, C., eds., Snow and Ice-Related Hazards, Risks and Disasters: Amsterdam, Elsevier, p. 563-606, https://doi .org/10.1016/B978-0-12-394849-6.00016-0.

Evans, S.G., Tutubalina, O.V., Drobyshev, V.N., Chernomorets, S.S., McDougall, S., Petrakov, D.A., and Hungr, O., 2009, Catastrophic detachment and high-velocity long-runout flow of Kolka glacier, Caucasus Mountains, Russia in 2002: Geomorphology, v. 105, p. 314-321, https://doi .org/10.1016/j.geomorph.2008.10.008.

Fairfield, J., and Leymarie, P., 1991, Drainage networks from grid digital elevation models: Water Resources Research, v. 27, p. 709-717, https:// doi.org/10.1029/90WR02658.

Falaschi, D., Kääb, A., Paul, F., Tadono, T., Rivera, J.A., and Lenzano, L., 2018, Brief communication: $4 \mathrm{Mm}^{3}$ collapse of a cirque glacier in the Central Andes of Argentina: The Cryosphere, v. 13 , p. $997-1004$, https://doi.org/10.5194/tc2018-201.

Gilbert, A., Leinss, S., Kargel, J., Kääb, A., Gascoin, S., Leonard, G., Berthier, E., Karki, A., and Yao, T., 2018, Mechanisms leading to the 2016 giant twin glacier collapses, Aru Range, Tibet: The Cryosphere, v. 12, p. 2883-2900, https://doi .org/10.5194/tc-12-2883-2018.

Gruber, S., 2012, Derivation and analysis of a highresolution estimate of global permafrost zonation: The Cryosphere, v. 6, p. 221-233, https:// doi.org/10.5194/tc-6-221-2012.

Haeberli, W., Huggel, C., Kääb, A., Zgraggen-Oswald, S., Polkvoj, A., Galushkin, I., Zotikov, I., and Osokin, N., 2004, The Kolka-Karmadon rock/ ice slide of 20 September 2002: An extraordinary event of historical dimensions in North Ossetia, Russian Caucasus: Journal of Glaciology, v. 50, p. 533-546, https://doi.org/10.3189/172756504 781829710 .

Hock, R., 2003, Temperature index melt modelling in mountain areas: Journal of Hydrology
(Amsterdam), v. 282, p. 104-115, https://doi .org/10.1016/S0022-1694(03)00257-9.

Ignéczi, Á., Sole, A.J., Livingstone, S.J., Ng, F.S.L., and Yang, K., 2018, Greenland Ice Sheet surface topography and drainage structure controlled by the transfer of basal variability: Frontiers of Earth Science, v. 6, https://doi.org/10.3389/feart.2018.00101.

Irvine-Fynn, T.D.L., Hodson, A.J., Moorman, B.J., Vatne, G., and Hubbard, A.L., 2011, Polythermal glacier hydrology: A review: Reviews of Geophysics, v. 49, p. 1-37, https://doi .org/10.1029/2010RG000350.

Iverson, N.R., Hoover, T.S., and Baker, R.W., 1998, Ring-shear studies of till deformation: Coulombplastic behavior and distributed strain in glacier beds: Journal of Glaciology, v. 44, p. 634-642, https://doi.org/10.1017/S0022143000002136.

Iverson, R.M., George, D.L., and Logan, M., 2016 , Debris flow runup on vertical barriers and adverse slopes: Journal of Geophysical Research: Earth Surface, v. 121, p. 2333-2357, https://do .org/10.1002/2016JF003933

Jacquemart, M., and Loso, M., 2019, Catastrophic glacier collapse and debris flow at Flat Creek, Wrangell-St. Elias National Park and Preserve: Alaska Park Science, v. 18, p. 47-55.

Jorgenson, T., Yoshikawa, K., Kanevskiy, M., Shur, Y., Romanovsky, V., Marchenko, S., and Grosse, G., 2008, Permafrost characteristics of Alaska, in Proceedings of the Ninth International Conference on Permafrost: Fairbanks, Alaska, Institute of Northern Engineering, University of Alaska Fairbanks, scale 1:7,200,000, http://permafrost.gi.alaska.edu/ sites/default/files/AlaskaPermafrostMap_Front Dec2008_Jorgenson_etal_2008.pdf.

Kääb, A., et al., 2018, Massive collapse of two glaciers in western Tibet in 2016 after surge-like instability: Nature Geoscience, v. 11, p. 114-120, https:// doi.org/10.1038/s41561-017-0039-7.

MacKevett, E.M., Jr., 1978, Geologic Map of the McCarthy Quadrangle, Alaska: U.S. Geological Survey Miscellaneous Investigations Series Map I-1032, scale 1:250,000.
Paul, F., 2019, Repeat glacier collapses and surges in the Amnye Machen mountain range, Tibet, triggered by a developing rock-slope instability: Remote Sensing, v. 11, https://doi.org/10.3390/rs11060708.

Planet Team, 2018, Planet Application Program Interface: In Space for Life on Earth: San Francisco, California, Planet: https://api.planet.com (accessed 24 January 2019).

Porter, C., et al., 2018, Arctic DEM: https://doi .org/10.7910/DVN/OHHUKH (accessed 20 September 2018)

Post, A., 1969, Distribution of surging glaciers in western North America: Journal of Glaciology, v. 8, p. 229-240, https://doi.org/10.1017/ S0022143000031221.

Prochaska, A.B., Santi, P.M., Higgins, J.D., and Cannon, S.H., 2008, A study of methods to estimate debris flow velocity: Landslides, v. 5, p. 431-444, https://doi.org/10.1007/s10346-008-0137-0.

RGI Consortium, 2017, Randolph Glacier Inventory-A Dataset of Global Glacier Outlines: Version 6.0: Randolph Glacier Inventory Consortium, https:// www.glims.org/RGI/ (accessed 5 July 2017).

Ryser, C., Lüthi, M., Blindow, N., Suckro, S., Funk, M., and Bauder, A., 2013, Cold ice in the ablation zone: Its relation to glacier hydrology and ice water content: Journal of Geophysical Research: Earth Surface, v. 118, p. 693-705, https:// doi.org/10.1029/2012JF002526.

Schwartz, D.P., Haeussler, P.J., Seitz, G.G., and Dawson, T.E., 2012, Why the 2002 Denali fault rupture propagated onto the Totschunda fault: Implications for fault branching and seismic hazards: Journal of Geophysical Research: Solid Earth, v. 117, p. 1-25, https://doi .org/10.1029/2011JB008918.

Wouters, B., Gardner, A.S., and Moholdt, G., 2019, Global glacier mass loss during the GRACE satellite mission (2002-2016): Frontiers of Earth Science, v. 7, p. 96, https://doi.org/10.3389/ feart.2019.00096.

Printed in USA 